\title{
Comparative Study of the Properties of Ripe Banana Flour, Unripe Banana Flour and Cooked Banana Flour Aiming Towards Effective Utilization of These Flours
}

\author{
Ravinder Singh $^{1 *}$, Suvartan Ranvir ${ }^{2}$ and Sukriti Madan ${ }^{1}$ \\ ${ }^{1}$ Food Science and Technology Department, Guru Nanak Dev University, Amritsar, \\ Punjab 143001, India \\ ${ }^{2}$ Dairy Chemistry Division, National Dairy Research Institute, Karnal, Haryana 132001, India \\ *Corresponding author
}

\section{A B S T R A C T}

Keywords

Ripe banana flour, Utilization, Data,

Cooked banana

flour.

Article Info

Accepted:

19 June 2017

Available Online:

10 August 2017
Ripe banana flour, unripe banana flour and cooked banana flour prepared from banana procured from local market were assessed for physicochemical and functional properties such as $\mathrm{pH}$, total soluble solids (TSS), water absorption capacities, and oil absorption capacities at 40, 60 and $80{ }^{\circ} \mathrm{C}$, colour values $L^{*}, a^{*}$ and $b^{*}$, bulk density foaming capacity and foaming stability, emulsion activity and stability, dispersibility and wet ability. Data obtained were analysed by standard deviation and average based. All statistical analyses showed that physicochemical and functional properties prepared from ripe green and cooked banana were different from each other. $\mathrm{pH}$, TSS, WAC, bulk density and colour values used to discriminate between ripe, unripe and cooked banana flour.

\section{Introduction}

Banana is one of the most consumed fruits in tropical and subtropical regions. The dessert banana has a global distribution, considering the nutrition aspect, it is the world's leading fruit crop, and crop, and in terms of economical value it is the number five agricultural crop in world trade. There are nearly hundered banana producing countries. As well as banana and plantain are among the world's leading fruit crops, there are very few $\mathrm{s}$ processed products issuing from these tropical productions. The worldwide production of bananas in 2012 was 139.2 million tonnes (FAOSTAT, 2012). Besides, world banana exports are projected to reach almost 17.9 million tonnes in 2011.
The 2012 statistics show that India led the world in banana production, producing around $18 \%$ of the worldwide crop of 139 million metric tonnes. More than $85 \%$ of global banana production is produced by small-scale farmers, providing an important source of food and income. Musa is one of the cheapest food crops to produce and the cost of production is less than most other staples. Besides been used primarily as dessert, banana fruit may be processed into pulpliquid fruit, canned slice, deep-fried chips, toffees, fruit bars, brandy and etc. (Kachru et al., 1995; Morton, 1987). In addition, the byproducts of banana such as the leaves, fibres and pseudostem extract have been reported to 
have some commercial value such as animal feeds, medicines and crafts.

Bananas are highly perishable, with a significant proportion of the harvested crop being lost from the farm gate to the market place, owing to poor handling, storage and transportation of the fresh fruits. Additionally, non-harvesting losses may occur in peak production periods.when farmers do not harvest the entirety of their production, because of saturated markets. Put together, an estimate of $35 \%$ loss of the production of bananas was reported for developing countries (FAO, 1987). And this is a very important thing is that $20-30 \%$ fruits can be utilized for flour processing,which is going to waste during the handling. By post-harvest technological tools we can reduce losses and increase the income of farmer's producing banana. For utilization of banana production as well as profitable farming in our country, In India more than 300 cultivars (AAA, AAB, $\mathrm{ABB}, \mathrm{AB}$ and hybrids) of banana are grown. It will be interesting to prepare banana flour from ripe fruits. Ripe banana flour can potentially offer new products with standardized composition for various industrial and domestic uses. Banana flour prepared from ripe banana containing a quantity of sugar is suitable for incorporation into food products requiring solubility, sweetness and high energy content. Physical properties of fresh banana and banana constituents such as banana starch, have been studied and characterized (Zhang et al., 2005), Commercial banana flour production is not yet common in Asia however this industry is gaining popularity in major banana producing countries in Africa (Emaga et al., 2008).

Green bananas are an excellent source of carbohydrates as well as nutritionally important bioactive compounds (OvandoMartinez et al., 2009). Moreover, unripe banana is a source of antioxidant polyphenols, which show strong protective effects against certain diseases, such as cancer, rheumatoid arthritis and cardiovascular disease (Chong and Noor Aziah, 2010; Ovando-Martinez et al., 2009). However, owing to the fact that banana is a climacteric fruit and due to the habit of consuming ripe fruit, large quantities of this commodity are lost during its commercialization and post-harvest handling. A new economic strategy is to process green bananas into dried flour and incorporate the flour into various innovative products so as to encourage consumption of banana and thus contribute to health benefits for humans (Ovando-Martinez et al., 2009; Ramli et al., 2010). Green banana flour contains up to 61.3-76.5 g/100 g starch on dry basis, a percentage comparable to that in the endosperm of corn grain and the pulp of white potato; apart from starch, GBF is high in total dietary fiber (6.28-15.54 g/100 g dry basis), which participates in the hypocholesterolaemic effect (Horigome et al., 1992; Mota et al., 2000; Zhang et al., 2005). New economical strategy to increase utilisation of banana includes the production of banana flour when the fruit is unripe, and to incorporate the flour into various innovative products such as slowly digestible cookies (Aparicio-Saguilan et al., 2007), high-fibre bread (Juarez-Garcia et al., 2006) and edible films. However, once the fruit is processed into flour, identification of the stages of ripeness of banana used for flour preparation becomes a challenge. As far as we know, no study has been conducted to compare physicochemical properties of flour prepared from ripe, unripe banana and cooked unripe banana. The physicochemical properties of the flour are expected to vary with stage of ripeness as it is known that the composition of banana changes dramatically during ripening. It seems worth-while to study the physicochemical data of banana flour and devise methods to discriminate ripe banana, unripe banana and cooked banana flour based 
on its physicochemical data. Statistical techniques that can be applied to perform this task include mean and standard deviation.

Therefore the objective of this study was. To prepare flours from ripe, unripe banana and cooked unripe banana, to compare the properties of ripe banana flour, unripe banana flour and cooked banana flour aiming towards effective utilization of these flours.

\section{Materials and Methods}

\section{Procurement of sample}

Ripe and unripe banana were procured from local market of Amritsar. One batch of unripe bananas was further cooked to prepare cooked banana flour. The entire chemicals used were of analytical grade.

\section{Preparation of flour}

\section{Unripe banana flour (UBF)}

Manufacturing process of unripe banana flour involved following step:

The fruit was washed and then peeled the unblemished mature green bananas. Sliced the bananas into $0.5-\mathrm{cm}$ thick pieces, to reduce enzymic browning, slices were then dipped in $0.5 \%(\mathrm{w} / \mathrm{v})$ citric acid solution for $10 \mathrm{~min}$, drained and dried in oven (Abbas F.M. Alkarkhi et al., 2011).

Drained the slices by placing them on trays with plastic mesh and then place them in the dryer. Dry in a hot-air dryer at temperature of $55^{\circ} \mathrm{C}$ until dry and brittle in approx. 24 hours then ground the dried banana chips in a grinder after that pass the grind sample in 55 mesh no. sieve. (British sieve standard), after sieving fine banana flour was obtained, packed the flour in polyethylene bags and seal themand store in a cool, dry place.

\section{Ripe banana flour (RBF)}

Manufacturing process of ripe banana flour involved the same steps as unripe banana flour except in case of ripe banana higher quantity of citric acid $10 \mathrm{mg}$ as antibrowning agent was added.

\section{Cooked banana flour (CBF)}

Water was boiled in container and unripe banana was dipped in boiling water for 15 minute. After 15 minute banana was removed from boiling water. Then peeled the cooked banana and cut into slices having thickness. $3 \mathrm{~mm}$. Then cooked banana slices were placed in cabinet dryer at temperature of $55^{\circ} \mathrm{c}$. For 24 hours.

After 24 hours cooked banana slices were removed from cabinet dryer. The banana slices were ground and passed through 55 mesh no. sieve. (British sieve standard). After sieving fine banana flour was obtained. Flour was packed in air tight container and stored for testing.

\section{Physico - chemical and functional properties of flour}

\section{pH, TSS}

The $\mathrm{pH}$ of the flour was measured using a Coming $\mathrm{pH}$ metre, model 10. Flour suspension $(8 \%(\mathrm{w} / \mathrm{v}))$ was stirred for $5 \mathrm{~min}$, allowed to stand for $30 \mathrm{~min}$, filtered and the $\mathrm{pH}$ of filtrate measured (Suntharalingam and Ravindran, 1993). Total soluble solids (TSS) in the same flour slurries were measured using an Atago refractometer (Atago PAL-1, Co. Ltd., Tokyo, Japan) (Salvador et al., 2007).

\section{Titratable acidity (\%)}

Titratable acidity is determined as the percent acid in a sample determined by titration with 
a standard base and stated in terms of predominant acid in the sample. $8 \%$ flour solution was made and stirred for 5 minutes. This aliquot was allowed to stand for 30 minutes. And then it was filtered through filter paper.

Titration was carried out with $0.1 \mathrm{~N} \mathrm{NaOH}$ using a few drops of $1 \%$ phenolphthalein solution as an indicator. Titre value was noted. Results were calculated as percent anhydrous malic acid.

$\%$ Titratable acidity expressed as: (Titre $\times$ normality of alkali $\times$ vol. made up $\times$ Eqv. wt. of acid $\times 100) /($ Volume of sample taken $\times$ wt. or volume of sample taken $\times 1000$ )

\section{Water and oil absorption capacities}

Water absorption of different flours was measured by the centrifugation method of Sosulski (1962).

The samples $(3.0 \mathrm{~g})$ were dispersed in $30 \mathrm{ml}$ of distilled water and placed in pre weighed centrifuge tubes. The dispersions were stirred occasionally, held for $30 \mathrm{~min}$, followed by centrifugation for $20 \mathrm{~min}$ at $3000 \mathrm{~g}$ at $40^{\circ} \mathrm{C}$, $60^{\circ} \mathrm{C}, 80^{\circ} \mathrm{C}$, respectively.

The supernatant was decanted, excess moisture was removed by draining for $25 \mathrm{~min}$ at $50^{\circ} \mathrm{C}$ and sample was reweighed. For the determination of oil absorption, the method of Lin, Humbert and Sosulski (1974) was used. Samples $(2 \mathrm{~g})$ were mixed with $25 \mathrm{ml}$. of oil in preweighed centrifuged and centrifuged for $20 \mathrm{~min}$ at $3000 \mathrm{~g}$.

The separated oil was then removed with a pipette and the tubes were inverted for $25 \mathrm{~min}$ to drain the oil prior to reweighing. The water and oil absorption capacities were expressed as grams of water or oil bound per gram of the sample.

\section{Color characteristics}

The instrumental measurement of flour colour was carried out in triplicate using an ultrascan VIS hunter lab (Hunter Associates laboratory Inc., Reston, VA, U.S.A). A glass cell containing samples was placed above the light source $\mathrm{L}^{*}, \mathrm{a}^{*}$ and $\mathrm{b}^{*}$ values were recorded. The $\mathrm{L}^{*}$ value indicates the lightness. The $\mathrm{a}^{*}$ value give the degree of redgreen color, with a higher positive $a^{*}$ value indicating more red. The $b^{*}$ value indicates the degree of yellow-blue color, with a higher positive $b^{*}$ value indicating more yellow.

\section{Bulk density}

The flour samples were gently filled into 10 $\mathrm{ml}$ graduated cylinders, previously tare. The bottom of each cylinder was gently tapped on a laboratory bench several times until there was no further diminution of the sample level after filling to the $10 \mathrm{ml}$ mark. This gives packed bulk density and in similar way without tapping just filling it loosely gives loose bulk density of the sample. Bulk density expressed as $=\mathrm{Wt}$. of sample per unit volume of sample $(\mathrm{g} / \mathrm{ml})$

\section{Foaming capacity and foaming stability}

The method of Lin et al., (1974) was used for the determination of foaming capacity (FC) and foam stability (FS) of different flours. The dispersions of samples in distilled water were homogenized, using a homogenizer (Yorco, India) at high setting for 2-3 min. The blend was immediately transferred into a graduated cylinder and the homogenizer cup was rinsed with $10 \mathrm{ml}$ of distilled water, which was then added to graduated cylinder. The volume was recorded before and after whipping. The foam stability of Flour at 3\% concentration at a time intervals of 10, 20, 30, 40 and 50 minutes was observed. Foam capacity of flour was also observed at different flour concentrations of $1 \%, 2 \%, 3 \%$, $4 \%$, and $5 \%$. 


\section{Calculations}

$\mathrm{FC}=$ expressed as volume increase due to whipping

$\mathrm{FS}=$ for this foam vol. changes in the graduated cylinder were recorded at intervals of $10,20,30$ and $50 \mathrm{~min}$ of storage.

\section{Emulsion activity and stability}

To determine emulsion activity $1 \mathrm{gm}$. sample was added to $10 \mathrm{ml}$ of distilled water and 10 $\mathrm{ml}$ of refined oil was added in graduated centrifuge tubes. Centrifugation was carried out at $2000 \mathrm{~g} / 15$ minutes. And emulsion activity was calculated using formula. Then the above sample was heated at $80^{\circ} \mathrm{C}$ for 30 minutes in a water bath and cooled for 15 minutes. Again it was centrifuged. And emulsion stability was calculated using formula.

\section{Calculations}

Emulsion activity expressed as (\%) Height of emulsion layer $\times 100 /$ Total height of mixture and Emulsion stability expressed (\%) as Height of emulsion $\times 100 /$ Initial height of emulsion layer

\section{Dispersibility}

To determine dispersibility, $3 \mathrm{gm}$. sample was taken and was pored over the surface of water in beaker. Time it took for powder to distribute itself over the surface of water and sink in water was noted.

\section{Wet ability}

$3 \mathrm{gm}$. flour was placed around pestle inside funnel so that pestle blocks funnel opening. Then pestle is lifted to allow flour to flow through stamp into beaker of water. As soon as all powder flow into beaker of water, a stopwatch is started and time it took for sample to be completely noted.

\section{Statistical analysis}

The data reported in all the tables are the average of triplicate observations. The data were subjected to statistical analysis (Tables $1-3)$.

\section{Results and Discussion}

\section{Physico - chemical and functional properties of flour}

\section{pH, total soluble solids (TSS) and titrable acidity}

The mean $\mathrm{pH}$ of flours ranged between 6.8 to 6.9 and ripe banana flour showed the highest $\mathrm{pH}$ whilst cooked banana flour showed the lowest, though the differences both the flours were not statistically significant (Table 1). The ripe banana flour had the maximum TSS of $6{ }^{\circ}$ Brix. While unripe banana flour showed the minimum TSS of $1.6^{\circ}$ Brix.TSS of cooked banana flour did not differ statistically from unripe banana flour sample (Table 1). The lower TSS of green banana flour is acceptable since it is known that amylase, glycosidase, phosphorylase, sucrose synthase and invertase can act in the degradation of starch and the formation and accumulation of soluble sugars (Emaga et al., 2007; Terra, Garcia and Lajolo, 1983). The titrable acidity of banana flours was of order; ripe banana flour >cooked banana flour > unripe banana flour. Unripe banana flour had the minimum titrable acidity (.09\%) (Table 1).

\section{Water Absorption Capacity (WAC)}

Water absorption represents the ability of the product to associate with water under conditions where water is limiting. Figure (1) represents the WAC of three types of banana flours. WAC of unripe banana flour was found to be $0.14 \mathrm{~g} / \mathrm{g}$ at $40^{\circ} \mathrm{C}$ which further 
increased to $0.6 \mathrm{~g} / \mathrm{g}$ at $60^{\circ} \mathrm{C}$ and $0.19 \mathrm{~g} / \mathrm{g}$ at $80^{\circ} \mathrm{C}$. WAC could be related to the physical state of starch (Waliszewski et al., 2003), dietary fiber and protein in the flour. It was the release of amylose which has the capacity to effectively bind water molecules that yielded a higher WAC (Rodri'guez-Ambriz et al., 2008). Ripe banana flour showed lowest WAC at all the measured temperature. WAC increased with the increase temperature in all three types of flour but the highest WAC was exhibited by cooked followed by unripe and ripe banana flour.

\section{Oil absorption capacity (OAC)}

Oil absorption of all three banana flours shows a wide range of variations. Temperature also affects OAC a lot. It was found that $\mathrm{OAC}$ of ripe banana flour was $0.12 \mathrm{~g} / \mathrm{g}$ at $40^{\circ} \mathrm{C}$ which showed a slight decline to $0.11 \mathrm{~g} / \mathrm{g}$ at $60^{\circ} \mathrm{C}$ and then again decline at $80^{\circ} \mathrm{C}$. Cooked banana flour and unripe banana flour showed no release of oil at $80^{\circ} \mathrm{C}$. Unripe banana flour at $60^{\circ} \mathrm{C}$ represented the highest $\mathrm{OAC}$ of $0.12 \mathrm{~g} / \mathrm{g}$ (Figure 2). OAC relates to the hydrophilic character of starches present in the flour (Rodriguez- Ambriz et al., 2008) that could be present in some quantity in ripe as well as in unripe banana flour. Good oil absorption capacities of the flours suggest that they may be useful in food preparations that involve oil mixing, such as in bakery products where oil is an important ingredient.

\section{Color characteristics}

The color and discoloration of flour depends upon intrinsic color of the banana flours or if any treatment was given to the banana. Hunter color values $\left(\mathrm{L}^{*}, \mathrm{a}^{*}, \mathrm{~b}^{*}\right)$ of all three types of flours are represented in table 1 . Significant differences were observed between different color parameters. $\mathrm{L}^{*}$ value of cooked banana flour was found to be 96.9. This results shows that cooked banana flour was white with highest value of $\mathrm{L}^{*}$ and ripe banana flour was somewhat dark with lowest value of $\mathrm{L}^{*}$ (72.57). The ripe banana flour was more red (high $\mathrm{a}^{*}$ ) and also more yellow (highest $b^{*}$ ).During ripening of banana, the flesh colour changes from the typical "opaque white" of a product with a high starch content to a "very soft yellow" as the yellowing of the skin intensifies (Salvador et $a l .$, 2007). It has been hypothesized that the variation in $b^{*}$ value among samples may be attributed to the amount of carbohydrates and protein content due to their role in the development of non-enzymatic browning (Jamin and Flores, 1998). Cooked banana flour was somewhat different from other flours in exhibiting highest $\mathrm{L}^{*}$ and lowest $\mathrm{a}^{*}$ and $b^{*}$ values.

\section{Bulk density}

Bulk density is defined as weight of fibre per unit volume, often expressed as $\mathrm{g} / \mathrm{ml}$ and is a good index of structural changes (Sreerama $e t$ al., 2009). Bulk density is obtained majority in two forms i.e. loose and packed bulk density. Cooked banana flour, showed the minimum bulk density i.e. $0.43 \mathrm{gm} / \mathrm{ml}$, (Figure 1). While ripe banana flour showed highest bulk density i.e. $0.63 \mathrm{~g} / \mathrm{ml}$. Bulk density ranged from 0.43 to $0.63 \mathrm{gm} / \mathrm{ml}$ was indicated for the flour produced, comparable to that obtained by other researchers (Fegbemi, 1999). This value is also comparable to that obtained for unripe banana flour reported earlier by Emperatríz et al., (.2008)

\section{Foam capacity}

Figure 4 represents Foam capacity of banana flours at different concentrations. The foam capacity of unripe banana flour showed highest values at different concentrations. FC of unripe banana flour at $1 \%$ concentration was $15 \%$ which increased to $51 \%$ at $5 \%$ concentration. The different flour samples of banana showed the different foaming capacity 
range at different concentrations. The higher Foam capacity at the alkaline $\mathrm{pH}$ has been attributed to the decreased hydrophobic forces among protein molecules (Aluko and Yada, 1995). Among all three banana flours the ripe banana flour showed the minimum capacity at all concentrations while maximum foaming capacity was observed in case of unripe banana flour.

Fig.1 Water absorption capacity of ripe banana flour (RBF), unripe banana flour (UBF), cooked banana flour (CBF)
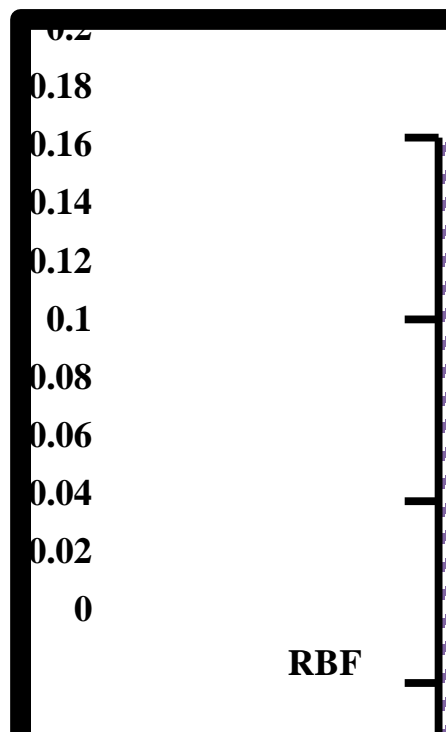

at 40 c

at $60 \mathrm{c}$

at 80 c

Fig.2 Oil absorption capacity of ripe banana flour (RBF), unripe banana flour (UBF), cooked banana flour (CBF)

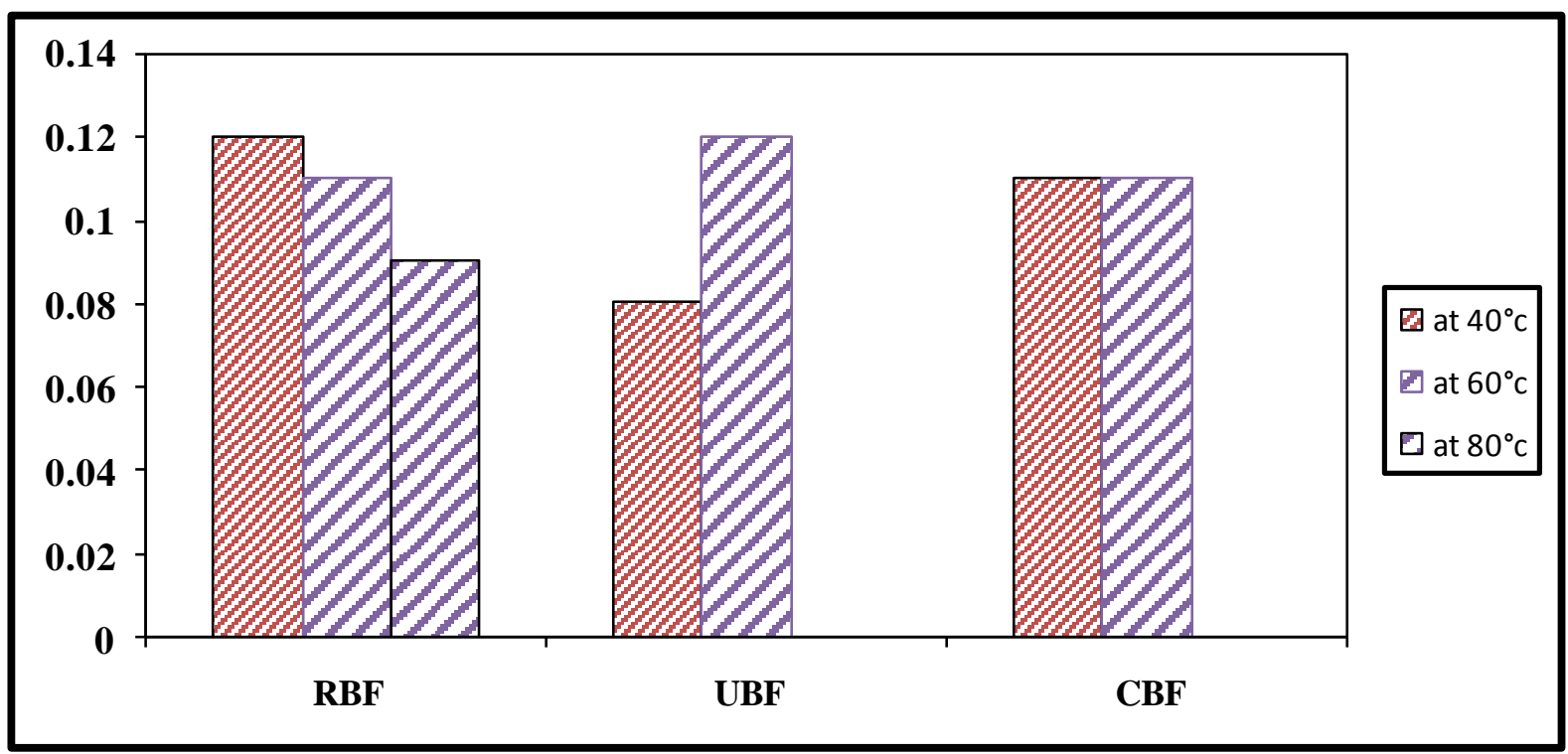


Fig.3 Packed bulk density of ripe banana flour (RBF), unripe banana flour (UBF), cooked banana flour $(\mathrm{CBF})$

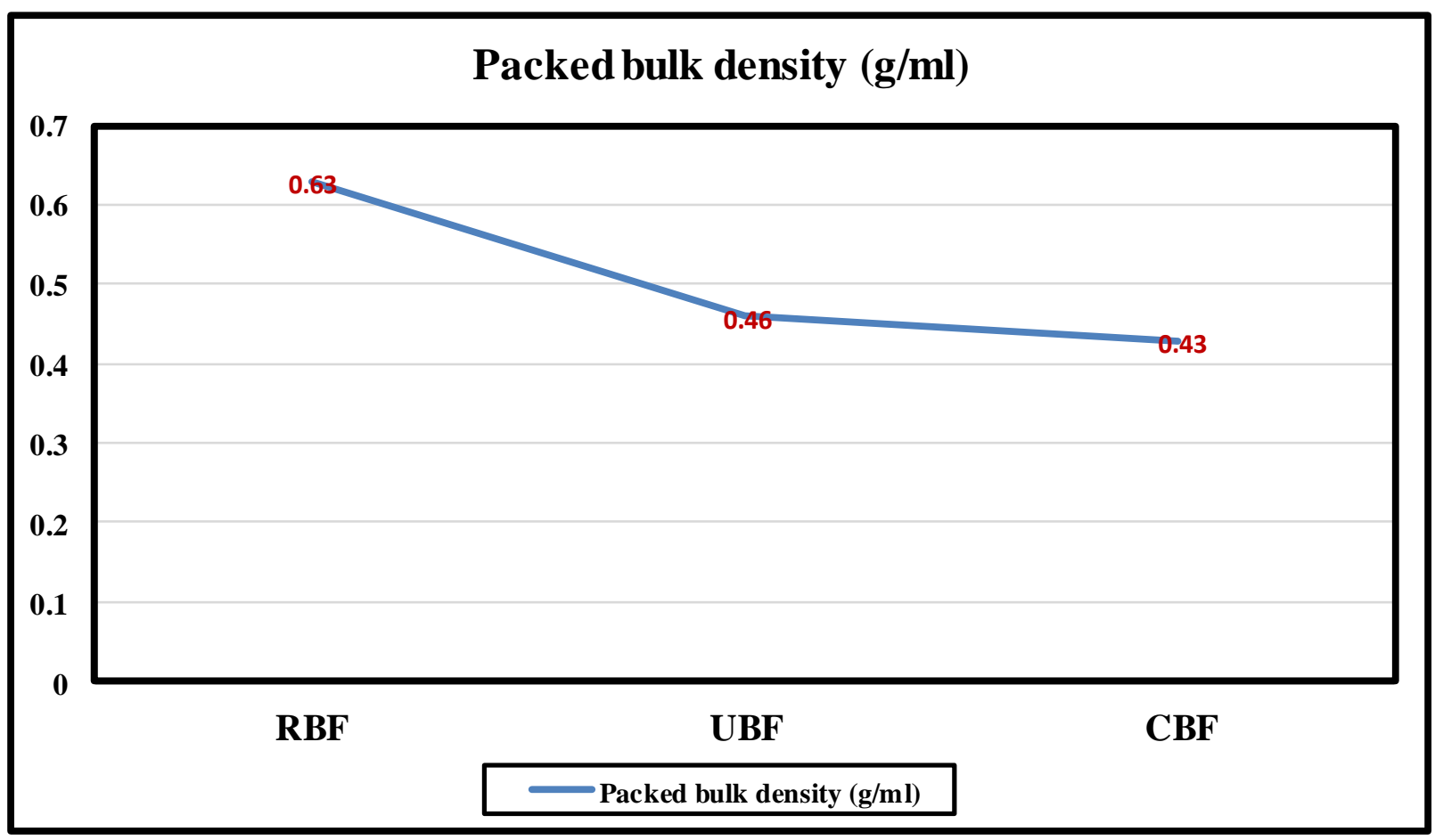

Fig.4 Foaming capacity of ripe banana flour (RBF), unripe banana flour (UBF), cooked banana flour (CBF)

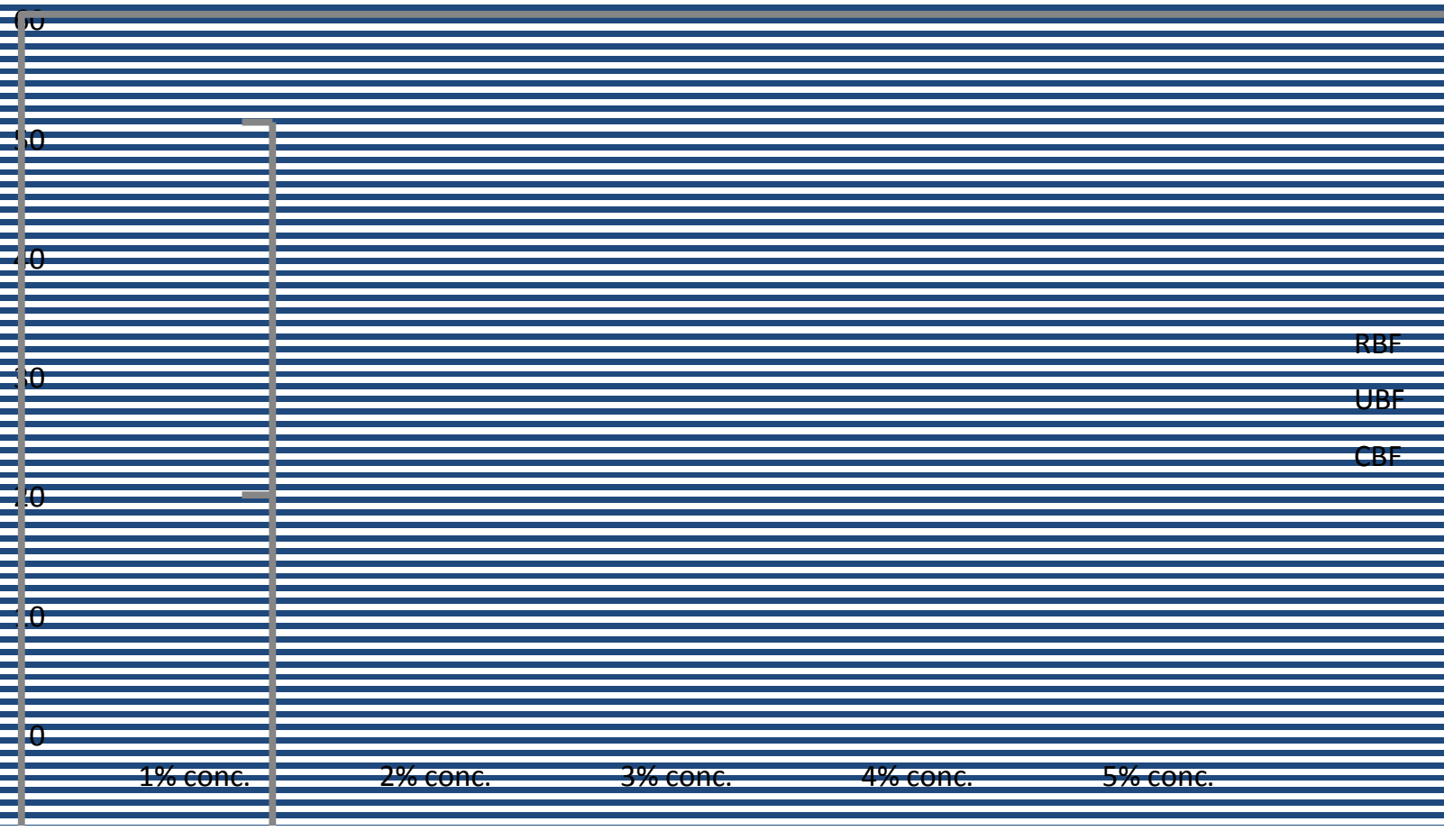


Fig.5 Foam stability of ripe banana flour (RBF), unripe banana flour (UBF), cooked banana flour $(\mathrm{CBF})$

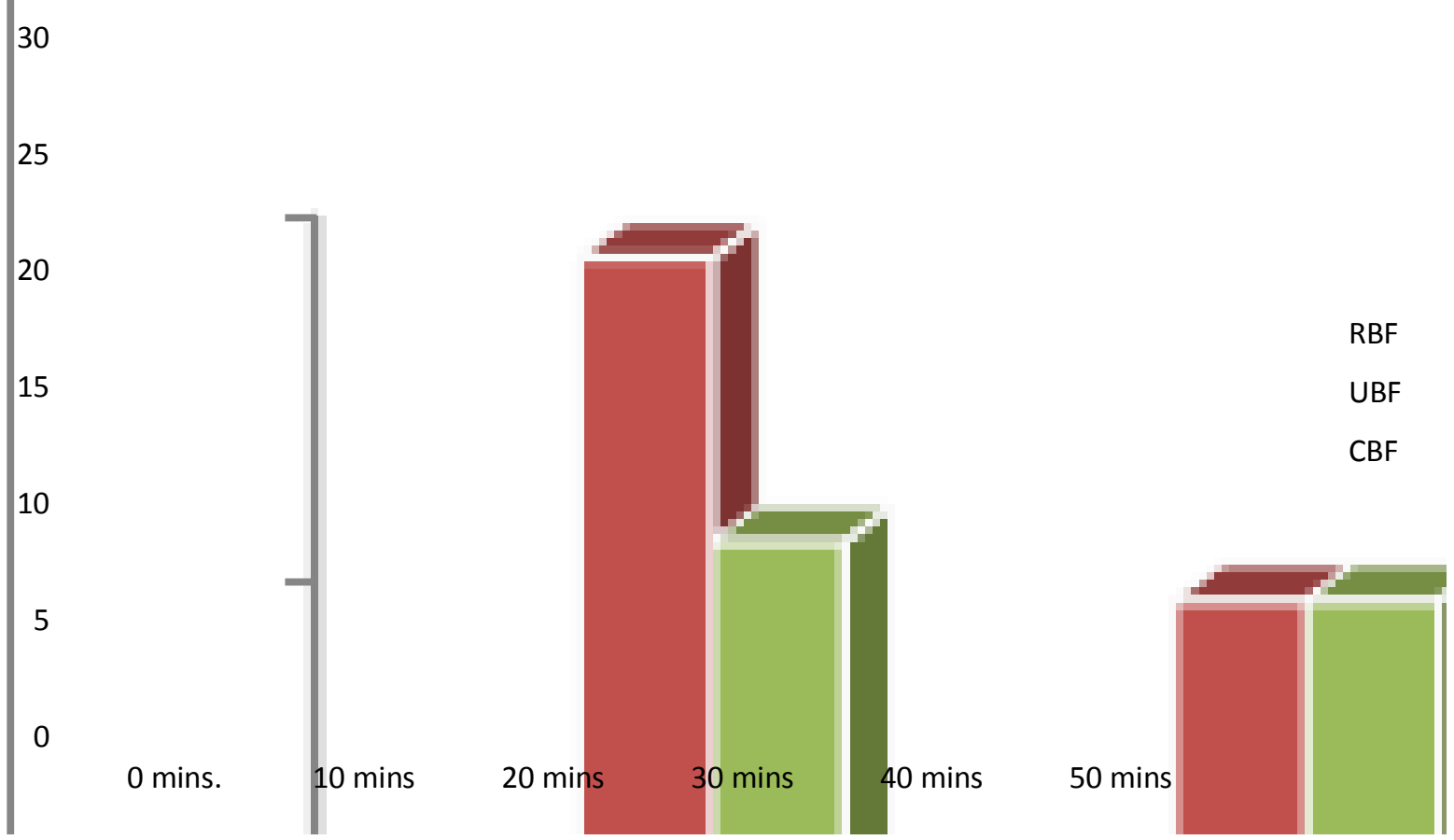

Fig.6 Emulsion activity and Emulsion stability of ripe banana flour (RBF), unripe banana flour (UBF), cooked banana flour $(\mathrm{CBF})$

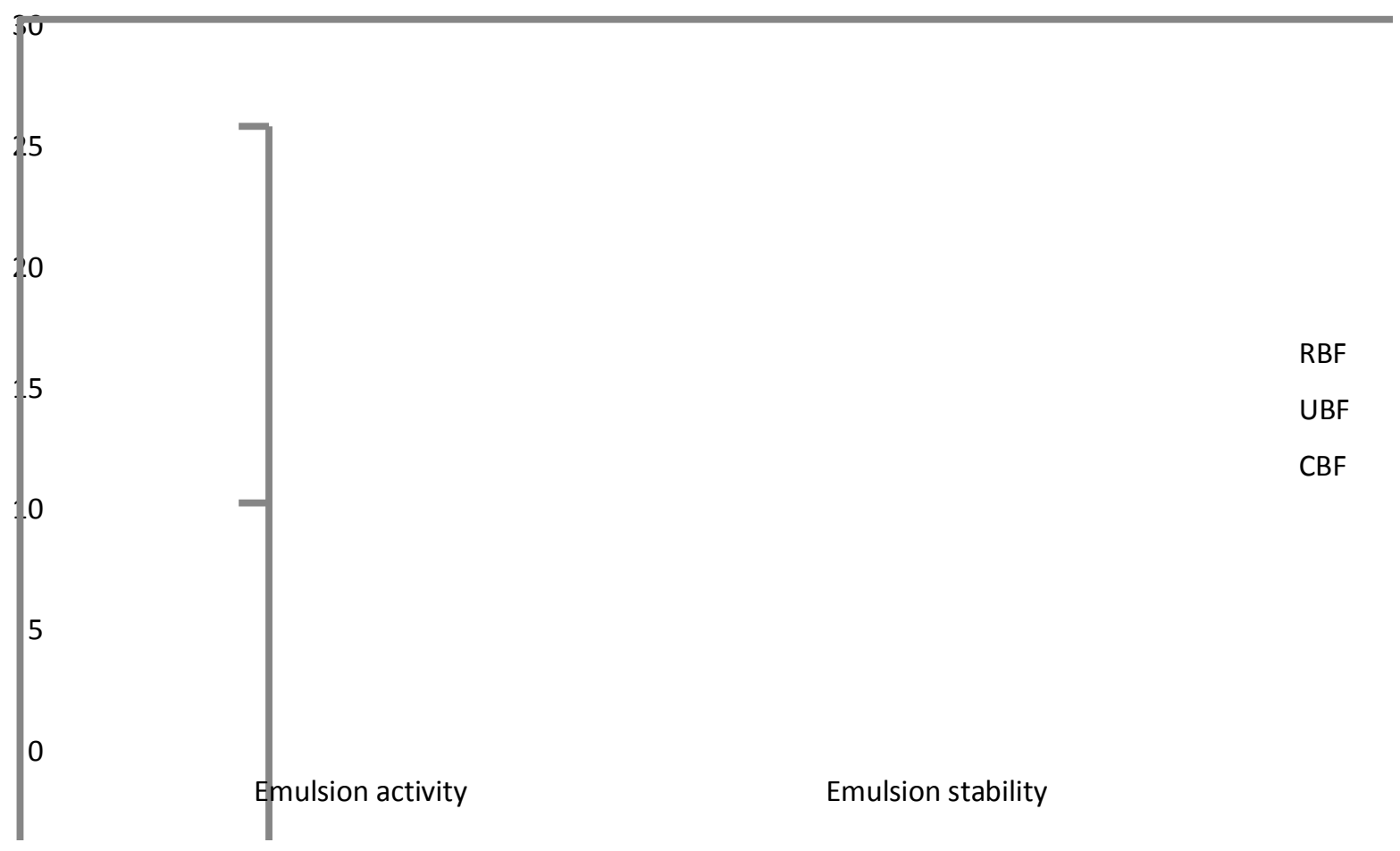


Table.1 Physico - chemical properties of ripe, unripe and cooked banana flour

\begin{tabular}{|l|l|l|l|}
\hline Sample & pH & TSS $\left(^{\circ}\right.$ Brix $)$ & Titrable acidity (\%) \\
\hline Ripe banana flour & $6.9^{\mathrm{a}}$ & $6^{\mathrm{b}}$ & $0.36^{\mathrm{b}}$ \\
\hline Unripe banana flour & $6.8^{\mathrm{a}}$ & $1.6^{\mathrm{a}}$ & $0.09^{\mathrm{a}}$ \\
\hline Cooked banana flour & $6.8^{\mathrm{a}}$ & $1.9^{\mathrm{a}}$ & $0.1^{\mathrm{b}}$ \\
\hline
\end{tabular}

Values reported in table are mean of triplicate observations.

Means followed by same later in a column do not differ significantly.

Table.2 Colour characteristics of ripe, unripe and cooked banana flour

\begin{tabular}{|l|l|l|l|}
\hline Sample & $\mathbf{L}^{*}$ & $\mathbf{a}^{*}$ & $\mathbf{b}^{*}$ \\
\hline Ripe banana flour & $72.57^{\mathrm{a}}$ & $3.82^{\mathrm{c}}$ & $16.9^{\mathrm{c}}$ \\
\hline Unripe banana flour & $92.47^{\mathrm{b}}$ & $2.4^{\mathrm{b}}$ & $14.6^{\mathrm{b}}$ \\
\hline Cooked banana flour & $96.9^{\mathrm{c}}$ & $1.80^{\mathrm{a}}$ & $10.74^{\mathrm{a}}$ \\
\hline
\end{tabular}

Values reported in table are mean of triplicate observations.

Means followed by same later in a column do not differ significantly

Table.3 Dispersibility and wettability of ripe, unripe, cooked banana flour

\begin{tabular}{|l|l|l|}
\hline Sample & Dispersibility (minutes) & Wettability (minutes) \\
\hline Ripe banana flour & $6^{\mathrm{a}}$ & $4^{\mathrm{a}}$ \\
\hline Unripe banana flour & $5^{\mathrm{a}}$ & $3^{\mathrm{a}}$ \\
\hline Cooked banana flour & $5^{\mathrm{a}}$ & $3^{\mathrm{a}}$ \\
\hline
\end{tabular}

Values reported in table are mean of triplicate observations.

Means followed by same later in a column do not differ significantly.

\section{Foam stability}

Figure 5 represents the foam stability of Banana Flour at $3 \%$ concentration after a time intervals of 10, 20, 30, 40 and 50 minutes. The foam of flour is due to proteins which form a continuous cohesive film around the air bubble in the foam (Njitang et al., 2001). Foam stability is governed by the ability of the film formed around the entrapped air bubbles to remain intact without draining, it follows that stable foams can only be formed by highly surface active solutes (Cherry and McWatters, 1981).

All the three banana flours showed a decrease in foam stability with passage of time. However lowest foam stability was exhibited by ripe banana followed by cooked and highest by unripe banana flour.

\section{Emulsion activity (EA) and stability (ES)}

Banana flours showed emulsion activity ranging from 6.3 to $9.3 \%$. Cooked banana flour showed highest emulsion activity i.e.9.3 (Figure 6), while ripe banana flour showed minimum EA i.e. $6.3 \%$. Emulsion stability of the flours ranged from 17.8 to $24.7 \%$. Unripe banana flour showed highest emulsion stability i.e. $24.7 \%$ while ripe banana flour showed minimum i.e. $17.8 \%$.

The net charge at the hydrophilic-lipophilic interface was dependent on the $\mathrm{pH}$ of solution and it may impede or facilitate emulsifying 
activity of proteins (Adebowale and Lawal, 2004).

\section{Dispersibility and wettability}

Dispersibility represents the dispersing property of the Banana Flours (Table 3). Unripe banana flour was similar to cooked banana flour showing 5 minutes dispersibility time (Table 3). Ripe banana flour took the maximum time to disperse 6 minutes. Wettability is the property of the Banana Flours to wet in water. The ripe banana flour showed the maximum wettability of 4 minutes which was lower than unripe and cooked banana flours i.e. 3 minutes (Table 3 ).

Studies were conducted to comparing physicochemical and functional properties of banana flours of ripe, unripe and cooked banana aiming towards effective utilization of these flours.

The titrable acidity of banana flours was of order ripe banana flour >cooked banana flour > unripe banana flour. WAC of unripe banana flour was found to be. $14 \mathrm{~g} / \mathrm{g}$ at $40^{\circ} \mathrm{C}$ which further increased to. $16 \mathrm{~g} / \mathrm{g}$ at $60^{\circ} \mathrm{C}$ and. $19 \mathrm{~g} / \mathrm{g}$ at $80^{\circ} \mathrm{C}$. Ripe banana flour showed the lowest WAC at all the measured temperature. WAC increase with the increase temperature all in three types of flour. Cooked banana flour and unripe banana flour showed no oil release at $80^{\circ} \mathrm{C}$. The drying in cabinet dryer darkened both the ripe and unripe flours giving the highest value of $a^{*}$ and $b^{*}$. Cooked banana flour was somewhat different from other flours in exhibiting highest $\mathrm{L}^{*}$ and lowest $\mathrm{a}^{*}$ and $b^{*}$ value. Cooked banana flour, showed the minimum bulk density i.e.. $43 \mathrm{~g} / \mathrm{ml}$. Among all three banana flours the ripe banana flour showed the minimum foaming capacity at all concentrations while maximum foaming capacity was observed in case of unripe banana flour. All the three banana flours showed a decrease in foam stability with increase in time. Banana flours showed emulsion activity ranging from 6.3 to 9.3\%.With Cooked banana flour showing highest emulsion activity, while ripe banana flour showed the minimum. The ripe banana flour showed the highest wettability while cooked banana flour showed the minimum wettability. Banana is undoubtfully of cultural, food and socioeconomic importance in the Indian society. Due to the low moisture content of the banana flour produced, it is expected to have a longer shelf-life; hence the product could ensure food security all year round as a result of the long storage life and the plentiful supply of ripe and unripe bananas available in the local Indian markets. Based on the functional characteristics and proximate composition of the banana flour product, it can be incorporated as a food thickener in foods for people of all ages.

\section{Acknowledgments}

Guru Nanak Dev University, Amritsar, is kindly acknowledged for providing financial support as well as technical assistance during the experimental work.

\section{References}

Adebowale, K. O., and Lawal, O. S. (2004). Comparative study of the functional properties of bambarra groundnut (Voandzeia subterranean), jack bean (Canavalia ensiformis) and mucuna bean (Mucuna pruriens) flours. Food Research International, 37(4), 355-365.

Alkarkhi, A. F., bin Ramli, S., Yong, Y. S., and Easa, A. M. (2011). Comparing physicochemical properties of banana pulp and peel flours prepared from green and ripe fruits. Food Chemistry, 129(2), 312-318.

Aluko, R. E., and Yada, R. Y. (1995). Some functional properties of a cowpea (Vigna unguiculata) globulin isolate 
treated with transglutaminase. Bioscience, biotechnology, and biochemistry, 59(12), 2298-2299.

Aparicio-Saguilán, A., Sayago-Ayerdi, S. G., Vargas-Torres, A., Tovar, J., AscencioOtero, T. E., and Bello-Pérez, L. A. (2007). Slowly digestible cookies prepared from resistant starch-rich lintnerized banana starch. Journal of Food composition and Analysis, 20(3), 175-181.

Cherry, J. P. (Ed.). (1981). Protein functionality in foods. American Chemical Society.

Choo, C. L., and Aziz, N. A. A. (2010). Effects of banana flour and $\beta$-glucan on the nutritional and sensory evaluation of noodles. Food Chemistry, 119(1), 3440.

Da Mota, R. V., Lajolo, F. M., Cordenunsi, B. R., and Ciacco, C. (2000). Composition and functional properties of banana flour from different varieties. Starch-Stärke, 52(2- 3), 6368.

Emaga, T. H., Andrianaivo, R. H., Wathelet, B., Tchango, J. T., and Paquot, M. (2007). Effects of the stage of maturation and varieties on the chemical composition of banana and plantain peels. Food chemistry, 103(2), 590-600.

Emaga, T. H., Robert, C., Ronkart, S. N., Wathelet, B., and Paquot, M. (2008). Dietary fibre components and pectin chemical features of peels during ripening in banana and plantain varieties. Bioresource

Technology, 99(10), 4346-4354.

Fagbemi, T. N. (1999). Effect of blanching and ripening on functional properties of plantain (Musa aab) flour. Plant Foods for Human Nutrition (Formerly Qualitas Plantarum), 54(3), 261-269.

FAO 2012a FAOSTAT Online Database (available at http://faostat.fao.org/, accessed September 2012)

FAO. 1987. Agriculture: Towards 2000. (Revised Version). FAO, Rome.

Horigome, T., Sakaguchi, E., and Kishimoto, C. (1992). Hypocholesterolaemic effect of banana (Musa sapientum L. var. Cavendishii) pulp in the rat fed on a cholesterol-containing diet. British Journal of Nutrition, 68(1), 231-244.

Jamin, F. F., and Flores, R. A. (1998). Effect of additional separation and grinding on the chemical and physical properties of selected corn dry-milled streams. Cereal Chemistry, 75(1), 166170.

Juarez-Garcia, E., Agama-Acevedo, E., Sáyago-Ayerdi, S. G., RodríguezAmbriz, S. L., and Bello-Perez, L. A. (2006). Composition, digestibility and application in breadmaking of banana flour. Plant Foods for Human Nutrition (Formerly Qualitas Plantarum), 61(3), 131-137.

Kachru, R. P., Kotwaliwale, N., and Balasubramanian, D. (1995). Physical and mechanical properties of green banana (Musa paradisiaca) fruit. Journal of food engineering, 26(3), 369-378.

Lin, M. J. Y., Humbert, E. S., and Sosulski, F. W. (1974). Certain functional properties of sunflower meal products. Journal of Food Science, 39(2), 368-370.

Linko, Y. Y., Miller, B. S., Johnson, J. A., Smith, H. E., Russell, C. R., Rist, C. E., and Hlynka, I. (1962). Quantitative determination of certain carbonyl compounds in pre-ferments. Cereal Chem, 39, 263-272.

Morton, J. F. (1987). Fruits of warm climates. JF Morton.

Njintang, N. Y., Mbofung, C. M. F., and Waldron, K. W. (2001). In vitro protein digestibility and physicochemical properties of dry red bean (Phaseolus 
vulgaris) flour: effect of processing and incorporation of soybean and cowpea flour. Journal of Agricultural and Food Chemistry, 49(5), 2465-2471.

Ovando-Martinez, M., Sáyago-Ayerdi, S., Agama-Acevedo, E., Goñi, I., and Bello-Pérez, L. A. (2009). Unripe banana flour as an ingredient to increase the undigestible carbohydrates of pasta. Food Chemistry, 113(1), 121126.

Ramli, S. B., Alkarkhi, A. F. M., Yong, Y. S., and Easa, A. M. (2010). Physicochemical properties of banana peel flour as influenced by variety and stage of ripeness: multivariate statistical analysis. Journal of Agricultural Science and Technology, 4, 1250-1939.

Rodríguez-Ambriz, S. L., Islas-Hernández, J. J., Agama-Acevedo, E., Tovar, J., and Bello-Perez, L. A. (2008). Characterization of a fibre-rich powder prepared by liquefaction of unripe banana flour. Food Chemistry, 107(4), 1515-1521.

Salvador, A., Sanz, T., and Fiszman, S. M. (2007). Changes in colour and texture and their relationship with eating quality during storage of two different dessert bananas. Postharvest biology and technology, 43(3), 319-325.

Sreerama, Y. N., Sashikala, V. B., and Pratape, V. M. (2009). Expansion properties and ultrastructure of legumes:
Effect of chemical and enzyme pretreatments. LWT-Food Science and Technology, 42(1), 44-49.

Suntharalingam, S., and Ravindran, G. (1993). Physical and biochemical properties of green banana flour. Plant Foods for Human Nutrition (Formerly Qualitas Plantarum), 43(1), 19-27.

Terra, N. N., Garcia, E., and Lajolo, F. M. (1983). Starch- Sugar Transformation during Banana Ripening: The Behavior of UDP Glucose Pyrophosphorylase, Sucrose Synthetase and Invertase. Journal of Food Science, 48(4), 1097-1100.

Waliszewski, K. N., Aparicio, M. A., Bello, L. A., and Monroy, J. A. (2003). Changes of banana starch by chemical and modification. Carbohydrate polymers, 52(3), 237-242.

Zhang, P., Whistler, R. L., BeMiller, J. N., and Hamaker, B. R. (2005). Banana starch: production, physicochemical properties, and digestibility-a review. Carbohydrate polymers, 59(4), 443-458.

Zhang, P., Whistler, R. L., BeMiller, J. N., and Hamaker, B. R. (2005). Banana starch: production, physicochemical properties, and digestibility-a review. Carbohydrate polymers, 59(4), 443-458.

\section{How to cite this article:}

Ravinder Singh, Suvartan Ranvir and Sukriti Madan. 2017. Comparative Study of the Properties of Ripe Banana Flour, Unripe Banana Flour and Cooked Banana Flour aiming Towards Effective Utilization of These Flours. Int.J.Curr.Microbiol.App.Sci. 6(8): 2003-2015. doi: https://doi.org/10.20546/ijcmas.2017.608.239 